(1) Birgül Özkesici
Kurt,
(1) Yeşim Şenol*;
(1) Özlem Dicle**

\section{Clinical Evaluation of Primary Cicatricial Alopecias from Turkey: A Retrospective Analysis of 97 Cases}

\author{
Türkiye' den Primer Sikatrisli Alopesilerin Klinik \\ Değerlendirmesi: 97 Olgunun Geriye Dönük Analizi
}

\section{Abstract}

Objective: Primary cicatricial alopecias (PCA) are a rare group of hair diseases with irreversible hair loss. The objective of the current study was to evaluate the demographic data, clinical findings, disease course and accompanying diseases in a series of PCA cases.

Methods: Retrospective analysis was performed on medical records of 97 patients diagnosed as PCA utilizing electronic data base search at Akdeniz University Hospital Hair Diseases Unit.

Results: The incidence of PCA among hair diseases was determined as $6 \%$. Lichen planopilaris (LPP) (41.2\%) was the most common diagnosis of PCA, followed by frontal fibrosing alopecia (FFA) (15.4\%) and dissecting cellulitis (9.3\%). The ratio of lymphocytic cicatricial alopecia to neutrophilic cicatricial alopecia was found 6.3:1. Female to male ratio was 1.8:1 ( $p<0.01)$. The mean age was $44.22 \pm 15.19$ years. The cases with FFA were significantly older (62.2 \pm 9.21 years) and folliculitis decalvans were significantly younger (17.5 \pm 4.95 years) $(p<0.01)$. The most frequent complaint of the patients was itching of the scalp (30\%) and $66.7 \%$ of the patients with itching had been diagnosed as LPP and FFA. No significant relationship was observed between PCA groups and the concominant diseases.

Conclusion: The gender and age distribution of the patients with PCA are similar to those described in the literature. LPP is the most frequent PCA diagnosis and the most frequent complaint is itching of the scalp in these patients.

Keywords: Clinical features, discoid lupus erythematosus, dissecting cellulitis, frontal fibrosing alopecia, lichen planopilaris, primary cicatricial alopecia

\section{Öz}

Amaç: Primer sikatrisli alopesiler (PSA) geri dönüşümsüz kıl kaybı ile seyreden nadir görülen bir grup saç hastalığıdır. Bu çalışmada bir seri PSA olgusunda, demografik verilerin, klinik bulguların, hastalık sürecinin ve eşlik eden hastalıkların değerlendirilmesi amaçlanmıştır. Yöntemler: Akdeniz Üniversitesi Hastanesi Saç Hastalıkları Ünitesi'nde PSA tanısı konulan 97 hastanın elektronik veri tabanı araştırması kullanılarak dosya verileri geriye dönük olarak değerlendirildi.

Bulgular: Saç hastalıkları arasında PSA görülme oranı \%6,0 olarak saptandı. Liken planopilaris (LPP) $(\% 41,2)$ en sık saptanan tan olup bunu frontal fibrozan alopesi (FFA) $(\% 15,4)$ ve dissekan selülit $(\% 9,3)$ izliyordu. Lenfositik sikatrisli alopesilerin nötrofilik sikatrisli alopesilere oranı 6,3:1 olarak bulundu. Kadın erkek oranı 1,8:1 olarak bulundu $(p<0,01)$. Ortalama yaş 44,22 $\pm 15,19$ yıl idi. FFA olguları anlamlı olarak daha ileri yaşta $(62,2 \pm 9,21$ yaş) ve folikülitis dekalvans olguları anlamlı olarak daha genç yaştaydı (17,5 $\pm 4,95$ yaş) $(p<0,01)$. En sık saptanan yakınma saçlı deride kaşıntı (\%30) olup kaşıntı yakınması olan hastaların \%66,7'sine LPP ve FFA olarak tanı konmuştu. PSA grupları ile eşlik eden hastalıklar arasında anlamlı bir ilişki saptanmadı.

Sonuç: PSA hastalarının cinsiyet ve yaş dağılımı literatürde tanımlananlarla benzerlik göstermektedir. En sık konulan PSA tanısı LPP'dir ve bu hastalarda en sık yakınma saçlı deride kaşıntı olarak saptanmıştır.

Anahtar kelimeler: Klinik özellikler, diskoid lupus eritematozus, dissekan selülit, frontal fibrozan alopesi, liken planopilaris, primer sikatrisli alopesi 


\section{Introduction}

Primary cicatricial alopecias (PCA) are a group of hair disease characterized by permanent hair follicle destruction and irreversible hair loss. Although, it's thought that the inflammation targeting the hair follicle results in the disease, the etiopathogenesis of PCA remains poorly understood (1). PCA were classified, according to a consensus meeting on cicatricial alopecia by North American Hair Research Society in 2001, into 3 main groups: lymphocytic, neutrophilic, and mixed, based on the histologically predominant type of inflammatory cells which is still in use (Table 1) (2). Today, optimal management and treatment guidelines for the PCA have not been established. They are relatively rare diseases and controlled trials are limited. In this group of diseases, demonstration of the demographic and clinical characteristics of the patients may lead the formation of patient profiles and clarification of the ethiopathogenetic mechanism by the identification of the potential trigger factors.

The aim of this study is to evaluate the demographic and clinical characteristics, disease process and accompanying diseases in a series of PCA patients in order to give information that will provide a better understanding of this group of diseases.

\section{Methods}

This retrospective descriptive study was carried out in a regional tertiary referral center for hair disorders in Turkey. All patients who admitted to the Akdeniz University Hospital Hair Diseases Unit from May 2011 to May 2014 and who had a diagnosis of PCA were included to the study. Data

\section{Table 1. Classification of primary cicatricial alopecias}

Lymphocytic primary cicatricial alopecia

- Chronic cutaneous lupus erythematosus

(discoid lupus erythematosus)

- Lichen planopilaris

Classic lichen planopilaris

Frontal fibrosing alopecia

- Graham Little syndrome

- Classic pseudopelade of Brocq

- Central centrifugal cicatricial alopecia

- Alopecia mucinosa

- Keratosis follicularis spinulosa decalvans

Neutrophilic primary cicatricial alopecia

- Folliculitis decalvans

- Dissecting cellulites/folliculitis

(perifolliculitis abscedens et suffodiens)

Mixed cicatricial alopecia

- Folliculitis (acne) keloidalis

- Folliculitis (acne) necrotica

- Erosive pustular dermatosis were collected utilizing electronic database search. The parameters including the patient demographics, symptoms noted at admission, duration of symptoms, diagnosis, diagnostic methods, serological tests and comorbidities such as diabetes mellitus, hypertension, coronary artery disease and thyroid disease were recorded. Patients' records were kept confidential.

\section{Statistical Analysis}

Data obtained from patients' digital records were analyzed by using SPSS version 18.0. Mean and standard deviation for quantitative variables and percentage for qualitative variables were calculated. The chi-square test and ANOVA test were used for statistical analysis. Fisher's exact test and Yatescorrected chi-square were performed if necessary. $\mathrm{P}$ value $<0.05$ was considered statistically significant.

\section{Results}

A total of 97 patients with PCA, identified among 1617 patients who evaluated in the Akdeniz University Hospital Hair Diseases Unit were enrolled in to the study. PCA were found to be $6.0 \%$ of all hair diseases. The age range of the patients was $14-82$ years with the mean age of $44.22 \pm 15.19$ years (female, $\mathrm{n}=62 ;$ male, $\mathrm{n}=35$ ). The diagnosis was established by clinical and dermoscopic examination and biopsy. The biopsy was mostly performed in patients with lichen planopilaris (LPP). Trichoscopy was done $90.7 \%$ of the patients and direct immunofluorescence was done $27.8 \%$ of the patients. Patients whose lesions were present for a long time and had no activity at least for 2 years and the diagnosis could not be confirmed were defined as late stage (LS)-PCA without final diagnosis. The types of PCA and demographic data of the patients are summarized in the Table 2.

In this cohort, the ratio of lymphocytic cicatritial alopecia to neutrophilic cicatricial alopecia was found 6.3:1. The most frequent type of PCA was LPP (41.2\%), followed by frontal fibrosing alopecia (FFA) (15.4\%). Among patients with PCA, female predominance was seen with a female to male ratio of 1.8:1 (chi-square: 29.6; $p<0.01$ ). While the most common type of PCA in women and men was LPP $(40.3 \%, 42.9 \%$; respectively) the second most common diagnosis in women was FFA (24.2\%) and in men was dissecting cellulitis (DC) (25.7\%). It was observed that all patients with FFA and central centrifugal cicatricial alopecia (CCCA) were female and all the patients with folliculitis decalvans (FD) and DC were male $(p<0.01)$ (Table 2).

The patients with FFA were the oldest and the patients with FD were the youngest age group; the mean age of 62.2 \pm 9.21 and 17.5 \pm 4.95 , respectively (Figure 1). In ANOVA analysis, used for assessing the age of the patients, there was a difference between the groups $(p<0.001)$. FFA and FD were found to differ from the other groups with the post hoc test.

Eighty of patients with final diagnosis were evaluated to the symptoms in the admission. In addition to hair loss and baldness, symptoms such as itching, burning, stinging, pain, pustules on the scalp, scaling, redness and woundcrust formation were also noted. There were one or more of 
these complaints together. Itching was the most prominent symptom (30\%). The $66.7 \%$ of patients with itching were patients with LPP. Pustules on the scalp was found to be the second most common complaint and, was found to be main symptom of the patients with DC and FD $(77.8 \%, 100 \%$; respectively). While patients with LPP were describing their unpleasant sensations such as burning, stinging and pain around the follicle, the patients with FD and DC were defined such sensations as pain on the scalp (Table 3).

When the time between the onset of the first symptoms and the admission of our unit was evaluated, it noted that the symptoms of $61.9 \%$ of patients were present for 1 to 5 years (Figure 2).

In our cohort, $13(86.7 \%)$ patients with FFA were in menopause, and the remaining 2 patients were also perimenopausal. Regarding of comorbidities, it was observed that hypertension

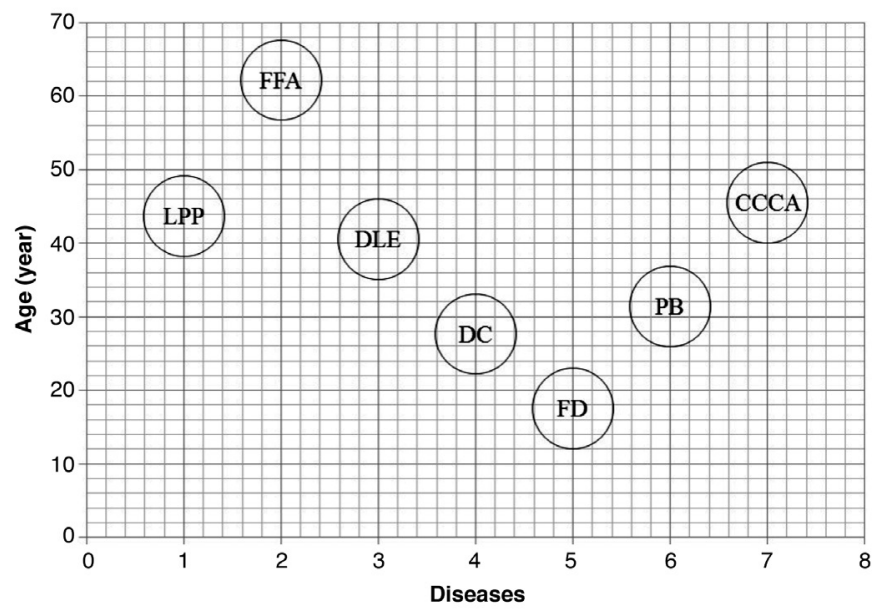

Figure 1. The mean age of patients with primary cicatricial alopecias

LPP: Lichen planopilaris, FFA: Frontal fibrosing alopecia, DLE: Discoid lupus erythematosus, DC: Dissecting cellulitis, FD: Folliculitis decalvans, PB: Pseudopelade of Brocq, CCCA: Central centrifugal cicatricial alopecia
(40\%) was often accompanying the patients with FFA. Serology for hepatitis $B$ and $C$ was performed on 28 patients with LPP and only 1 patient was found as hepatitis B carrier. A total of 46 patients were evaluated for thyroid autoantibodies [anti-thyroid peroxidase (TPO) and anti-human thyroglobulin (HTG)] and 14 (30.4\%) cases had elevated levels. In terms of concomitant thyroid disease in the history, it was detected that the incidence was $12.5 \%$ in all patients and most common in patients with LPP (20\%). In general, in the terms of accompanying diseases to the type of PCA, there was no statistically significant difference in statistical analysis (chisquare: 6.1, p>0.05) (Table 4).

\section{Discussion}

PCA are a relatively rare diseases in the practice of dermatology. In the literature, the prevalenced PCA were reported ranging between $2.1 \%-7.3 \%$ in the hair diseases (3-5). In these studies, as in our study, the prevalence of PCA seems to be higher in evaluations made in the centers that specialized in hair diseases than general dermatology clinics. In the study of Whiting (3), which is the first report and has the largest series,

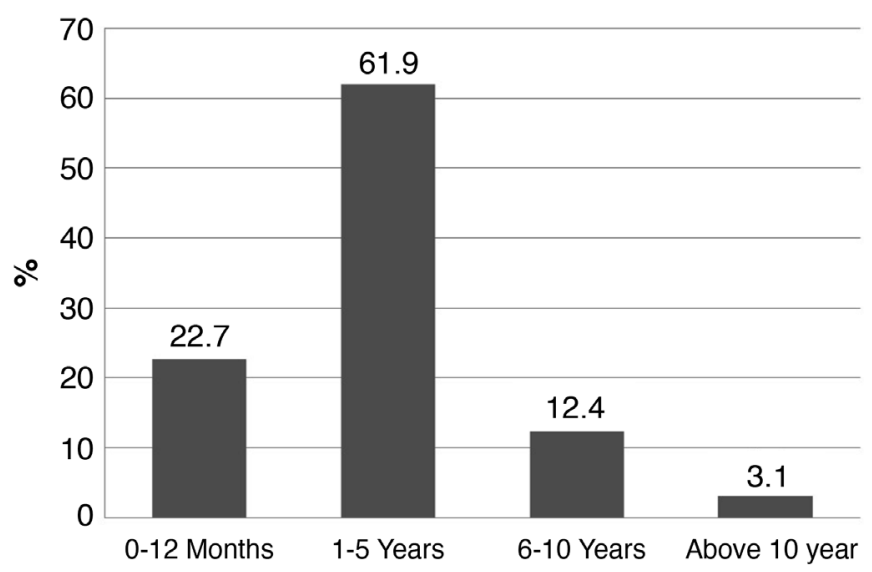

Figure 2. The time elapsed between the onset of symptoms and the admission of the hair diseases unit

Table 2. Types of primary cicatricial alopecias and demographic data of the patients

\begin{tabular}{|l|l|l|l|l|}
\hline Disease & $\begin{array}{l}\text { Number of the patients } \\
\mathbf{n}(\%)\end{array}$ & $\begin{array}{l}\text { Biopsy cases } \\
\mathbf{n}(\%)\end{array}$ & $\begin{array}{l}\text { Gender } \\
\text { Female-male } \\
\mathbf{n}(\%)\end{array}$ & $\begin{array}{l}\text { Age (year) } \\
\text { Min-max } \\
(\mathbf{M e a n} \pm \text { SD) }\end{array}$ \\
\hline LPP & $40(41.2)$ & $26(65)$ & $25(62.5)-1(37.5)$ & $17-67(43.73 \pm 11.91)$ \\
\hline FFA & $15(15.4)$ & $8(53.3)$ & $15(100)-0(0)$ & $48-77(62.2 \pm 9.21)$ \\
\hline DC & $9(9.3)$ & $2(22.2)$ & $0(0)-9(100)$ & $18-51(27.67 \pm 10.78)$ \\
\hline DLE & $7(7.2)$ & $3(42.7)$ & $5(71.4)-2(28.6)$ & $17-50(40.57 \pm 12.44)$ \\
\hline PB & $5(5.2)$ & $4(80)$ & $1(50)$ & $21-37(31.4 \pm 6.19)$ \\
\hline FD & $2(2.1)$ & $2(100)$ & $2(100)-0(0)$ & $14-21(17.5 \pm 4.95)$ \\
\hline CCCA & $2(2.1)$ & $4(23.5)$ & $12(70.6)-5(29.4)$ & $36-55(45.5 \pm 13.44)$ \\
\hline LS-PCA & $17(17.5)$ & $50(51.5)$ & $62(63.9)-35(36.1)$ & $27-82(46.53 \pm 14.68)$ \\
\hline Total & $97(100)$ & $14-82(44.22 \pm 15.19)$ \\
\hline $\begin{array}{l}\text { LPP: Lichen planopilaris, FFA Frontal fibrosing alopecia, DC: Dissecting cellulitis, DLE: Discoid lupus erythematosus, PB: Pseudopelade of Brocq, FD: Folliculitis decalvans, CCCA: } \\
\text { Central centrifugal cicatricial alopecia, LS-PCA: Late stage primary cicatricial alopecias, SD: Standard deviation }\end{array}$ \\
\hline
\end{tabular}


358 cases who applied to the hair diseases clinic and whose diagnosis of PCA confirmed histologically in 10-year period were evaluated. Although, secondary cicatricial alopecias caused by tinea capitis, late stage androgenetic alopecia and tractional alopecia were included, the vast majority of the study group was PCA cases (80\%). In this study pseudopelad (32.4\%) was the most common diagnosis, and followed by LPP (10.1\%), FD (8.9\%), discoid lupus erythematosus (DLE) (8.7\%) and acne keloidalis (8.4\%). However, the term pseudopelad had been used to define all non-specific scarring alopecia whose definitive diagnosis could not be reached (3).

Tan et al. (4) observed that most of the biopsy specimens of 112 PCA cases were histologically predominantly lymphocytic in a 5-year retrospective study and, the ratio of lymphocytic to neutrophilic PCA was reported as 4:1. DLE (33.9\%), pseudopelad (24.1\%) and LPP (22.3\%) were the most frequently diagnosed diseases (4). The lowest ratio of PCA (2.1\%) in the hair diseases was reported in a study from China. In this study 59 patients with PCA were evaluated in 6-year period, unlike other studies neutrophilic cicatricial alopecia was found more than lymphocytic ones (1.3:1) (5). The most common type of PCA observed in the studies differs among geographical regions. While LPP (25.7\%) was the most common diagnosis in the study of Trachsler and Trueb (6), FD was the first one in a study from China with the ratio of $40.7 \%$. In another study from Brazil, 39 patients were evaluated, and the most common diagnosis was found as DLE (43.6\%) (7). In a study from Iran with the evaluation of 100 patients with PCA in a 7-year period, $\mathrm{FD}(30 \%)$ was the first one (8). Although, this can be explained by ethnic differences, the results may also have been affected by the methodology of studies and the differences of the centers. In a survey, conducted in the United Kingdom, it was found that while the diagnosis of FFA was as high as $35.3 \%$ in an admission of trichologists, it decreased to $15 \%$ in general dermatologists. The same survey showed that patients with acne keloidalis and DLE more commonly applied to the general dermatology clinics than hair clinic (general clinic-hair clinic: $19.6 \%-13.8 \%$; 20.6\%-12.7\%; respectively) (9). In the present study the number of cases with DLE (7.2\%) was quite less compared to other studies. Similarly, this finding suggests that DLE cases often applied to the general dermatology clinic. On the other hand, the high rate of cases with FFA (15.4\%) in our series may depend on that the study was carried out in the hair disorders clinic.

In this study, the biopsy was done to $51.3 \%$ of all PCA patients. Histopathological examination was done mostly in

Table 3. Main symptoms of the patients (except hair loss and/or baldness)

\begin{tabular}{|c|c|c|c|c|c|c|c|c|}
\hline Symptoms & $\begin{array}{l}\text { LPP } \\
n=40\end{array}$ & $\begin{array}{l}\text { FFA } \\
n=15\end{array}$ & $\begin{array}{l}\text { DC } \\
n=9\end{array}$ & $\begin{array}{l}\text { DLE } \\
\mathbf{n}=7\end{array}$ & $\begin{array}{l}P B \\
n=5\end{array}$ & $\begin{array}{l}\text { FD } \\
n=2\end{array}$ & $\begin{array}{l}\text { CCCA } \\
\mathbf{n}=2\end{array}$ & $\begin{array}{l}\text { Total } \\
\mathrm{n}=\mathbf{8 0}\end{array}$ \\
\hline Itch, n (\%) & $16(40)$ & $4(26.7)$ & $1(11.1)$ & $2(28.6)$ & $1(20)$ & 0 & 0 & $24(30)$ \\
\hline Burning, n (\%) & $4(10)$ & $2(13.3)$ & $1(11.1)$ & $2(28.6)$ & $1(20)$ & 0 & 0 & $10(12.5)$ \\
\hline Stinging, n (\%) & $1(2.5)$ & $1(6.7)$ & $1(11.1)$ & 0 & $1(20)$ & 0 & 0 & $4(5)$ \\
\hline Scaling, n (\%) & 0 & $1(6.7)$ & 0 & 0 & 0 & 0 & 0 & $1(1.3)$ \\
\hline Redness, n (\%) & 0 & 0 & 0 & 0 & $1(20)$ & 0 & 0 & $1(1.3)$ \\
\hline Wound-crust, n (\%) & $3(7.5)$ & 0 & $3(33.3)$ & 0 & $1(20)$ & 0 & 0 & $7(8.8)$ \\
\hline No complaint, n (\%) & $20(50)$ & $10(66.7)$ & 0 & $5(71.4)$ & $3(60)$ & 0 & 0 & $38(47.5)$ \\
\hline
\end{tabular}

Table 4. Comorbidities in patients with primary cicatricial alopecias

\begin{tabular}{|l|l|l|l|l|l|}
\hline PCA & $\begin{array}{l}\text { DM } \\
\mathbf{n}(\%)\end{array}$ & $\begin{array}{l}\text { HT } \\
\mathbf{n}(\%)\end{array}$ & $\begin{array}{l}\text { CAD + HT } \\
\mathbf{n}(\%)\end{array}$ & $\begin{array}{l}\text { Dyslipidemia } \\
\mathbf{n}(\%)\end{array}$ & $\begin{array}{l}\text { TD } \\
\mathbf{n}(\%)\end{array}$ \\
\hline LPP, $\mathrm{n}=40$ & $3(7.5)$ & $4(10)$ & $5(12.5)$ & $3(7.5)$ & $8(20)$ \\
\hline FFA, $\mathrm{n}=15$ & $3(20)$ & $6(40)$ & $7(46.7)$ & $3(20)$ & $1(6.7)$ \\
\hline DC, $\mathrm{n}=9$ & 0 & 0 & 0 & 0 & 0 \\
\hline DLE, $\mathrm{n}=7$ & 0 & $1(14.3)$ & $1(14.3)$ & 0 & $1(14.3)$ \\
\hline PB, $\mathrm{n}=5$ & 0 & 0 & 0 & 0 & 0 \\
\hline FD, $\mathrm{n}=2$ & 0 & 0 & 0 & 0 & 0 \\
\hline CCCA, $\mathrm{n}=2$ & 0 & 0 & 0 & 0 & 0 \\
\hline Total, $\mathrm{n}=80$ & $6(7.5)$ & $11(13.75)$ & $13(16.25)$ & $6(7.5)$ & $10(12.5)$ \\
\hline
\end{tabular}

PCA: Primary cicatricial alopecias, LPP: Lichen planopilaris, FFA: Frontal fibrosing alopecia, DC: Dissecting cellulitis, DLE: Discoid lupus erythematosus, PB: Pseudopelade of Brocq, FD: Folliculitis decalvans, CCCA: Central centrifugal cicatricial alopecia, DM: Diabetes mellitus, HT: Hypertension, CAD: Coronary artery disease, TD: Thyroid disease 
lymphocytic types of PCA, such as the patients with CCCA, pseudopelade of Brocq (PB), LPP, FFA and DLE (100\%, $80 \%$, $65 \%, 53.3 \%, 42.7 \%$; respectively). Whiting (3), in his paper suggested that in chronic cases clinical findings were more helpful to the diagnosis and immunofluorescence evaluation contributed to the diagnosis only in $27 \%$ of their cases. Another study showed that the biopsy was done more frequently in lymphocytic PCA (DLE, PB, LPP). Despite the fact that the differential diagnosis and classification of PCA were based on type of inflammatory infiltrate, the diagnosis of neutrophilic PCA was often depend on clinical findings. The biopsy ratio in all PCA cases was reported as $23.1 \%$ (9). In our study, histopathological examination was done in about half of the cases for the diagnosis, and immunofluorescence examination rate was $27.8 \%$. Although this can be seen as a limitation of the retrospective methodology, histopathological and immunofluorescence examination rates of the present study are consistent with the literature. On the other hand, trichoscopic examination was used in almost all cases (97.3\%) for the diagnosis. In recent years, an increasing number of distinctive dermoscopic examination findings were defined for PCA. And today, beside clinical signs trichoscopy (dermoscopy of the scalp) have being used more and more widely in the diagnosis and follow-up of these patients (10-12).

In the study $17(17.5 \%)$ patients were in the late stage. So, they had non-specific clinicopathological findings and whose disease activity has not been detected at least for 2 years, which were defined as "burn-out". When the patients applied in this stage, follicular destruction had been completed, fibrous tissue settled and there was no inflammatory infiltrate. These are common late stage findings of all PCA. In this stage reaching a definitive diagnosis, even in experienced centers is not always possible (1). While the term of pseudopelade is regarded as a separate entity in general, by some researchers it is also considered as the common end stage of many cicatricial alopecia $(13,14)$. The frequency of pseudopelad within all PCA was reported as $40.6 \%, 24.1 \%$ and $10 \%$ in the studies conducted in different hair diseases centers $(3,4,6)$. The differences between the studies are based on the demographic characteristics of patients, the properties of the centers or clinicopathological diagnostic criteria of pseudopelad. Therefore, in this study we prefer to classify cases with LS-PCA as a separate title, besides of classic PB cases.

In the literature in general, as also in our study, while lymphocytic cicatricial alopecias were more frequent in women, neutrophilic ones were more frequent in men $(4,5,13,15-20)$. In a study from Iran, Nejad et al. (8) reported that in their case series men were more frequently affected to PCA than women. And, they linked this data with the sociocultural differences such as the covering of their heads and women's home life (8).

The mean age of our patients with PCA was $44.22 \pm 15.19$ years. The patients with FFA were the oldest, the patients with FD were the youngest group and the difference was statistically significant. The similar mean age of PCA was reported in the literature $(3,5,7,13,15)$. Meinhard et al. (20) were found that patients with FFA were more elderly than LPP was statistically significant.

Regarding the main symptoms of our patients in admission, we found that the most frequent symptom was itching, followed by pustules on the scalp. According to the type of PCA, $40 \%$ of patients with LPP and $26.7 \%$ of patients with FFA were found to apply with the complaint of itching. The most common symptom in LPP and FFA is also reported as itching in the literature $(15,16,21)$. Tan et al. (4) described the most prominent symptoms of LPP as itching of the scalp (90\%) and pain $(72 \%)$. As a symptom, pustule formation on the scalp was more frequent in neutrophilic PCA, with $77.8 \%$ of the DC and $100 \%$ of the FD. We believe that the symptoms of itching and pustules on the scalp should be a warning sign for the diagnosis of PCA.

On the other hand, in the study the time period between the onset of the patients' first symptoms and admission to our unit was also remarkable. More than three-quarters of the patients expressed their complaints for more than 1 year at the application. In the study of Tan et al. (4) this period is under 1 year in the majority of cases with LPP and DLE. The mean time period for the diagnosis was reported as 3.7 years only for cases with pseudopelad because of the difficulty of clinicopathological diagnosis (4). As a result of our study it was thought that late application can be an important issue in our region.

When the concomitant diseases of 80 cases with final diagnosis were evaluated, it was found that comorbidities were higher in patients with FFA who were the group of advanced age. In this group, $40 \%$ hypertension, $20 \%$ diabetes mellitus, $20 \%$ dyslipidemia and $6.7 \%$ thyroid disease were detected. In a multicenter study, including 355 FFA cases, accompanying comorbidities were reported as $25 \%$ dyslipidemia, $15 \%$ hypothyroidism, $9 \%$ hypertension (15). In our study despite high rates of accompanying diseases in FFA, there was no statistically significant relationship between the types of PCA and comorbidities. In addition, $86.7 \%$ of patients with FFA were in menopause, and the remaining 2 patients were perimenopausal with menstruation irregularities. In several studies, more than $80 \%$ of the FFA patients were also reported as postmenopausal (15-17). Probably, more common accompanying diseases in this group of PCA is associated with advanced mean age and postmenopausal cases. In a study conducted in Germany, 104 patients with LPP and FFA were evaluated, no difference between patients with LPP and the general population in terms of hypertension and metabolic diseases was reported. Thyroid diseases were observed more frequent in patients with FFA than LPP. But, this may be associated with being postmenopausal and can be explained by subclinical hypothyroidism that become obvious in the postmenopausal period. Again, in the same study although viral hepatitis was considered as a trigger of the disease in patients with lichen planus, the same togetherness was not observed for the LPP and reported that doing serologic tests for hepatitis was not necessary 
in the patients with LPP (20). Similarly, Chieregato et al. (22) were reported that the routine serology of hepatitis $B$ and $C$ and the values of autoantibodies were normal in patients with LPP. In present study, serology for hepatitis B and C have done in 28 patients with LPP and, only 1 patient was detected as hepatitis B carrier. Besides hepatitis serology, thyroid autoantibodies (anti-TPO and anti-HTG) were evaluated in a total of 46 patients and was detected high in 14 (30.4\%) of these cases. The anti-TPO and/or anti-HTG antibody positivity was detected in $8(32 \%)$ of 25 patients with LPP, 5 of 11 patients with FFA (22\%) and 1 of 4 patients with pseudopelad. In terms of concomitant thyroid disease in the personal history, this ratio was $12.5 \%$ in all patients, higher in patients with LPP (20\%). In a study of Atanaskova Mesinkovska et al. (23) it was noted that the LPP may be accompanied with thyroid disease. In this case-control study, the ratio of thyroid disease was found as $34 \%$ in patients with LPP and especially association of hypothyroidism (29\%) was highlighted (23). In the studies that evaluated patients with DLE who has cicatricial alopecia, antinuclear antibodies (ANA) positivity has been reported as $15.8 \%$ and $42.8 \%(4,24)$. On the other hand, none of the patients with DLE had ANA positivity in this study. Relatively small number of patients with DLE may explain this difference.

\section{Study Limitations}

The retrospective methodology is the limitation of this study.

\section{Conclusion}

PCA were $6 \%$ of the hair diseases in our region. It was more frequently in women. LPP was the most commonly diagnosed PCA in our region. We believe that, itching and pustules accompanied with scarring alopecia should be the warning signs leading to diagnosis of PCA for this group of patients. Although in the present study, there was no statistically significant association in terms of concomitant diseases, should be careful in terms of thyroid disease especially in patients with LPP and FFA. The retrospective methodology is the limitation of this study. We believe that further multicenter national prospective researches supporting to the demographic and clinicopathological data on patients with PCA will make an important contribution to better understanding of this diseases.

\section{Ethics}

Ethics Committee Approval: Retrospective study.

Informed Consent: Retrospective study.

Peer-review: Internally peer-reviewed.

\section{Authorship Contributions}

Surgical and Medical Practices: Ö.D., B.Ö.K., Concept: Ö.D., Design: Ö.D., Data Collection or Processing: B.Ö.K., Y.Ş., Analysis or Interpretation: Ö.D., Y.Ş., B.Ö.K., Literature Search: Ö.D., B.Ö.K., Writing: Ö.D., B.Ö.K.
Conflict of Interest: No conflict of interest was declared by the authors.

Financial Disclosure: The authors declared that this study received no financial support.

\section{References}

1. Harries MJ, Trueb RM, Tosti A, et al. How not to get scar(r)ed: pointers to the correct diagnosis in patients with suspected primary cicatricial alopecia. $\mathrm{Br}$ J Dermatol 2009;160:482-501.

2. Olsen EA, Bergfeld WF, Cotsarelis G, et al. Summary of North American Hair Research Society (NAHRS)-sponsored workshop on cicatricial alopecia, Duke University Medical Center, February 10 and 11, 2001. J Am Acad Dermatol 2003;48:103-10.

3. Whiting DA. Cicatricial alopecia: clinico-pathological findings and treatment. Clin Dermatol 2001;19:211-25.

4. Tan E, Martinka M, Ball N, et al. Primary cicatricial alopecias: clinicopathology of 112 cases. J Am Acad Dermatol 2004;50:25-32.

5. Qi S, Zhao Y, Zhang X, et al. Clinical features of primary cicatricial alopecia in Chinese patients. Indian J Dermatol Venereol Leprol 2014;80:306-12.

6. Trachsler S, Trueb RM. Value of direct immunofluorescence for differential diagnosis of cicatricial alopecia. Dermatology 2005;211:98-102.

7. Moure ER, Romiti R, Machado MC, et al. Primary cicatricial alopecias: a review of histopathologic findings in 38 patients from a clinical university hospital in Sao Paulo, Brasil. Clinics (Sao Paulo) 2008;63:747-52.

8. Nejad SB, Khodaeiani E, Amirinia M, et al. Evaluation of cicatricial alopecia in Iran. Pak J Biol Sci 2013;16:1609-11.

9. Griffin LL, Michaelides C, Griffiths CE, et al. Primary cicatricial alopecias: a U.K. survey. $\mathrm{Br} J$ Dermatol 2012;167:694-7.

10. Rakowska A, Slowinska M, Kowalska-Oledzka E, et al. Trichoscopy of cicatricial alopecia. J Drugs Dermatol 2012;11:753-8.

11. Gökdemir G, Arı S. Sikatrisyel alopeside dermoskopik bulgular. Türkderm 2013;47:223-6.

12. Abedini R, Kamyab Hesari K, Daneshpazhooh M, et al. Validity of trichoscopy in the diagnosis of primary cicatricial alopecias. Int J Dermatol 2016;55:110614.

13. Ross EK, Tan E, Shapiro J. Update on primary cicatricial alopecias. J Am Acad Dermatol 2005;53:1-37.

14. Alzolibani AA, Kang $\mathrm{H}$, Otberg $\mathrm{N}$, et al. Pseudopelade of Brocq. Dermatol Ther 2008;21:257-63.

15. Vañó-Galván S, Molina-Ruiz AM, Serrano-Falcón C, et al. Frontal fibrosing alopecia: a multicenter review of 355 patients. J Am Acad Dermatol 2014;70:670-8.

16. Samrao A, Chew AL, Price V. Frontal fibrosing alopecia: a clinical review of 36 patients. Br J Dermatol 2010;163:1296-300.

17. Chew AL, Bashir SJ, Wain EM, et al. Expanding the spectrum of frontal fibrosing alopecia: a unifying concept. J Am Acad Dermatol 2010;63:653-60.

18. Kang $\mathrm{H}$, Alzolibani AA, Otberg $\mathrm{N}$, et al. Lichen planopilaris. Dermatol Ther 2008;21:249-56.

19. Whiting DA, Olsen EA. Central centrifugal cicatricial alopecia. Dermatol Ther 2008;21:268-78.

20. Meinhard J, Stroux A, Lünnemann L, et al. Lichen planopilaris: epidemiology and prevalence of subtypes- a retrospective analysis in 104 patients. J Dtsch Dermatol Ges 2014;12:229-36.

21. Lyakhovitsky A, Amichai B, Sizopoulou C, et al. A case series of 46 patients with lichen planopilaris: Demographics, clinical evaluation, and treatment experience. J Dermatolog Treat 2014;1:1-5.

22. Chieregato C, Zini A, Barba A, et al. Lichen planopilaris: report of 30 cases and review of the literature. Int J Dermatol 2003;42:342-5.

23. Atanaskova Mesinkovska N, Brankov N, Piliang M, et al. Association of lichen planopilaris with thyroid disease: a retrospective case-control study. J Am Acad Dermatol 2014;70:889-92.

24. Fabbri P, Amato L, Chiarini C, et al. Scarring alopecia in discoid lupus erythematosus: a clinical, histopathologic and immunopathologic study. Lupus 2004;13:455-62. 